\title{
Provisions for Individual Differences in the Teaching of Reading
}

\section{W. W. Theisen}

To cite this article: W. W. Theisen (1920) Provisions for Individual Differences in the Teaching of Reading, The Journal of Educational Research, 2:2, 560-571, DOI: 10.1080/00220671.1920.10879088

To link to this article: http://dx.doi.org/10.1080/00220671.1920.10879088

曲 Published online: 15 Dec 2014.

Submit your article to this journal \lceil

Q View related articles $\sqsubset$ 


\title{
PROVISIONS FOR INDIVIDUAL DIFFERENCES IN THE TEACHING OF READING ${ }^{1}$
}

\author{
W. W. THeisen \\ Director of Educational Measurements, State Deparlment of Public \\ Instruction, Madison, Wisconsin
}

The results of standardized tests have everywhere revealed wide differences in reading ability. They have shown decided variations in such factors as rate of reading, knowledge of vocabulary, ability to gather thought from the printed page, and ability to read orally. Diagnostic analyses of results such as those made by Miss Zirbes ${ }^{2}$ and others throw additional light on the nature of these differences. But in spite of all the facts brought to light, few attempts have been made in classroom teaching to provide adequately for individual differences in reading ability. The question is what can be done and what is being done by successful teachers.

The first question which this study seeks to answer is: What provisions for individual differences are employed by teachers generally considered successful in the teaching of reading? It is a matter of common observation that the average teacher does not satisfactorily make such provisions. For that reason we have tried to limit our study to strong teachers. The main purpose has been to find out what provisions are in actual use by such teachers and which provisions can be recommended to teachers in general.

Our second question is: What suggestions for the less experienced teacher can be gained from the study? E.g., What values have the various provisions which we have found to be in use? Are the most valuable always among those most favored? Which ones are suitable for the different grades?

Light was also sought on these additional questions: Are even these teachers of acknowledged success widely conscious of the problem? How far do they avail themselves of the means at hand?

${ }^{1}$ An address delivered before the National Association of Directors of Educational Research at Cleveland, Ohio, February 26, 1920.

${ }^{2}$ Zirbes, Laura. "Diagnostic measurement as a basis for procedure," Elementary School Journal, 18:505-22, March, 1918. 


\section{Method of the Study}

A letter was sent to a number of supervisors and superintendents of schools where there was reason to expect good instruction in reading with the request that a few of the best teachers be asked to reply. Copies of a circular stating the nature of the inquiry were inclosed for the benefit of the teachers. The circular merely asked that the person write us in detail telling what means she was using in the teaching of reading to provide for individual differences. She was requested also to offer suggestions as to methods that she thought could be used. Of the 123 replies received 118 were used in the study. A few appeared to have misinterpreted our request. The 118 were distributed on a percentage basis as indicated in Table I.

The results of this inquiry will be referred to throughout as the original study. After the first group of returns had been tabulated, a suggestive list containing the provisions listed in Table I, without figures, was sent to those who had replied and to a number of other strong teachers. On this list each person was asked to check the provisions which he or she used in teaching. The object was to provide a check on the results obtained in the original study.

\section{The Provisions Found}

For the present we shall confine the treatment to the original inquiry. The provisions found may be divided for convenience into two general divisions. The first we may designate as extraclassroom and the second as intra-classroom. Those belonging to the first have to do more with the steps preliminary to actual classroom procedure. In the extra-classroom division are two groups of provisions that offer us some assistance in solving the problem of individual needs. They apply not only to reading but to all subjects. (1) Attention to physical needs. (2) A flexible system of promotions. The intra-classroom provisions may be classed under seven headings in Table I: (A) Testing of individual abilities; (B) Grouping of pupils within the classroom; (C) Gradation of materials; (D) Variation in amount of reading practice; (E) Personal attention given to individuals; (F) Adaptation to and development of individual interests; $(G)$ Specific forms and phases of instruction-or what may be called "methods." 
TABLE I. PROVISIONS FOR INDIVIDUAL DIFFERENCES IN THE TEACHING OF READING REPORTED ORIGINAL STUDY

(A) Testing of Individual Abilities

1. Tests of rate and comprehension.......

2. Intelligence tests

(B) Grouping of pupils

1. Pupils arranged in small groups by ability

2. Pupils in small groups nol by ability.

(C) Gradation of materials read

1. Graded to fit individual ability .........

2. Selected by pupil's own choosing.......

3. Portions in oral reading or dramatizing assigned according to individual ability

(D) Variation in amount of reading practice

1. Voluntary reading in free periods.......

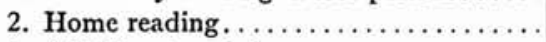

3. Additional periods.

4. Poorer called on more frequently in oral recitation.

5. Rapid cover more in silent reading.....

(E) Personal attention to individuals

1. Special help for specific defects. ........

2. Use of better pupils to help poorer.....

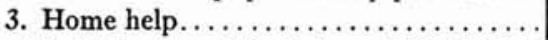

(F) Adaplation to and devclopment of individual interests

1. Materials chosen for individual interests

2. Individual choice of parts............

3. Best read for inspiration to poorer.....

(G) Specific forms and phases of instruction

1. Centering attention upon thought

a. Silent reading

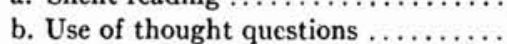

c. Illustrate material read by drawing

d. Thought drills

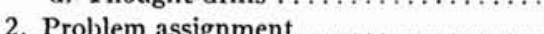

3. Motivation

4. Dramatization for certain pupils not included under C-3..............

5. Word and phonic drills..............

6. Phrase drills.

7. Speed drills.

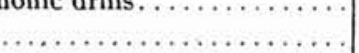

\begin{tabular}{|c|c|c|c|c|}
\hline \multicolumn{5}{|c|}{$\begin{array}{l}\text { Percent Reporting the } \\
\text { USE of Each Provision }\end{array}$} \\
\hline $\begin{array}{l}\text { Pri- } \\
\text { mary }\end{array}$ & $\begin{array}{l}\text { Inter- } \\
\text { medi- } \\
\text { ate }\end{array}$ & $\begin{array}{c}\text { Gram- } \\
\text { mar }\end{array}$ & $\begin{array}{c}\text { Super- } \\
\text { visors }\end{array}$ & All \\
\hline 6 & 32 & 29 & 46 & 24 \\
\hline 6 & 0 & 0 & 0 & 3 \\
\hline 58 & 39 & 14 & 54 & 45 \\
\hline 3 & 7 & 14 & 8 & 6 \\
\hline 42 & 32 & 7 & 46 & 34 \\
\hline 10 & 20 & 21 & 23 & 16 \\
\hline 8 & 7 & 14 & 15 & 9 \\
\hline 40 & 22 & 21 & 23 & 29 \\
\hline 27 & 44 & 29 & 23 & 32 \\
\hline 15 & 5 & 7 & 23 & 11 \\
\hline 0 & 0 & 7 & 8 & 3 \\
\hline 4 & 7 & 7 & 0 & 5 \\
\hline 46 & 44 & 43 & 46 & 44 \\
\hline 38 & 20 & 14 & 23 & 26 \\
\hline 4 & 2 & 21 & 0 & 5 \\
\hline 8 & 22 & 29 & 31 & 18 \\
\hline 4 & 2 & 7 & 8 & 4 \\
\hline 2 & 5 & 0 & 0 & 3 \\
\hline 65 & 83 & 71 & 77 & 65 \\
\hline 27 & 51 & 43 & 15 & 36 \\
\hline 6 & 7 & 0 & 0 & 5 \\
\hline 3 & 27 & 21 & 8 & 14 \\
\hline 4 & 2 & 0 & 8 & 3 \\
\hline 54 & 54 & 36 & 23 & 48 \\
\hline 3 & 10 & 7 & 15 & 7 \\
\hline 35 & 39 & 29 & 54 & 41 \\
\hline 19 & 29 & 7 & 31 & 23 \\
\hline 0 & 17 & 29 & 23 & 14 \\
\hline
\end{tabular}

Note: Percentages are computed on the basis of returns from 118 teachers and supervisors distributed as follows: Primary grades 1 and 11,48 ; intermediate, grades 111, IV, and v, 41 ; grammar, grades v1, vit, v111, 14; supervisors, 13; ungraded, v; not specified, 1. Geographically they represent 13 states. 
We shall dwell only very briefly on the two groups under the extra-classroom division, as these are usually outside of the control of the classroom teacher. As regards health, it may be said that cases of individual differences often call for physical attention. Every school system should provide for expert diagnosis and treatment of physical defects. Many teachers believe that pupils would receive instruction more nearly suited to their needs under a genuinely flexible system of promotion. This would undoubtedly aid in the solution of our problem. But these provisions are usually administrative matters, and as such are outside of the scope of our study.

Let us now consider the measures which we have called intraclassroom or teaching. The various provisions under the seven group headings are given in Table I. The percent of frequency for the different classes of teachers and for all combined is shown. Testing of individual abilities is placed first because it is logically the first step. Adequate provision for individual differences cannot be made without testing and analytical study of the abilities of pupils. Diagnosis, in education as in medicine, must precede prescription. It is significant that only one-fourth of the teachers considered the application of educational tests of sufficient importance to be mentioned. The use of intelligence tests was indicated by but 3 percent of them. We may be charitable in the case of intelligence tests as few teachers are either trained to give them or able to call upon anyone else to do so. But we can no longer excuse any but possibly first-grade teachers for failure to apply educational tests and to utilize the findings as a basis for intelligent procedure.

We have as one proposal for meeting individual differences the grouping of pupils of a grade into several small groups. Grouping together pupils of approximately equal abilities was among the three provisions most frequently mentioned. Another form of grouping is sometimes used, although it is of somewhat doubtful merit as a specific provision for individual differences. It is used in oral reading recitations, and consists in dividing the class into smaller units without attempting to place pupils of equal abilities together. The underlying theory apparently is that individual needs are met in part if the individual's opportunity for reading is increased. 
The particular merit of grouping on the basis of ability is that it permits gradation of materials. If pupils having similar weaknesses and instructional needs are grouped, the treatment of their special deficiencies can be carried on apart from the remainder of the class. An application of this method may be seen in the study by Miss Zirbes to which reference has already been made.

Gradation of materials furnishes an important means of providing for differences in ability. The aim here is to allow each pupil to read material suited to his development. Thirty-four percent of the teachers reported that they attempt to choose material fitted to individual abilities. Nine percent say that they attempt to base the assignment of portions of the lesson in oral reading or in dramatizing upon individual abilities. Sixteen percent allow pupils to select materials for themselves. Naturally a child rarely chooses material so difficult that he does not enjoyit.

Individual differences in reading ability can be cared for in part also through variations in the amount of reading practice. Variations in practice can be afforded through voluntary reading in free periods, home reading, group assignments, and individual assignments. Some provide additional class periods. The brighter may read with an advanced section. The weaker may read with a lower section or remain after school for an extra period. The advisability of the latter may be questioned. Calling upon the poorer pupils more frequently in the oral recitation, as employed by a few of our correspondents, is indefensible from the standpoint of the brighter pupils.

Personal attention is a common method of meeting the requirements of individuals. By this means, it is hoped to give each child or group such attention as is needed to remove specific weaknesses. Mass drill is apt to be uneconomical to say the least. Pupils can be assisted with their difficulties through individual or group attention on the part of the teacher (while others engage in silent reading), through assistance from stronger pupils, and through home help. Of the three types listed in the table special help from the teacher is most often given. The use of the better pupils to aid the poorer, a practice that is open to question, is mentioned all too frequently. Too many teachers seem obsessed with the notion that abilities should be "levelled off" as one teacher expressed it, rather than permitted to make a natural 
development. Home help does not appear to be popular with teachers.

In the judgment of a number of our correspondents, individual reading needs can be satisfied further by developing and utilizing the child's own interests and choosing his reading material accordingly. The table shows, however, that only a small percent suggested provisions that could be classed under interest. Only 18 percent, ostensibly, are making efforts to have material chosen in accordance with individual interests. The showing of the primary teachers is lamentable. The teacher must seek to discover a child's impelling interests as a basis for the choice of materials for him. In the words of one teacher, "Every child shows more interest in some one thing than another. The greatest difficulty is experienced in trying to find where this natural interest lies. This is the key which must be found in order to help him interpret new experiences."

To meet individual interests adequately every school must provide an abundance of material. This is where many fail. Good material for primary grades remains largely to be written. It is almost impossible to find any considerable number of books based upon worth-while interests of children and suitable for first or second grades. We impose upon the good nature and submissiveness of children by putting them through the dry, artificial, and disjointed material of method readers, or fool them into liking stories founded upon superficial interests and built upon unreal situations.

The final group of provisions of Table I entitled specific forms and phases of instruction includes provisions that pertain more to the teaching process. Our aim should be to furnish such teaching as will most nearly fit individual needs and permit maximum individual development. This can be accomplished, to an extent, by choosing methods that permit independent progress. This is doubtless the thought underlying "silent reading," which was suggested more often than any other single provision. The problem method is especially suitable for permitting independent progress. The unfamiliarity of teachers with this method and with its possibilities is emphasized by the fact that only 3 percent of the teachers mentioned it.

Our program for individual development can be carried out further by the choice of methods that center attention primarily 
upon thought and the development of right habits of thinking. The child who develops such habits becomes morenearly independent. These considerations underlie such provisions as are listed under the caption of "centering attention upon thought."

We can do something for children by supplying incentives that lead to independent efforts. Motivation in some form is quite prominent with each class of teachers represented in the table. Some of the suggestions classed under this heading include the preparation of a story to be read to the class, test charts upon which the individual can note his own progress, dramatizing (especially in lower grades), and contests of various sorts.

Instruction for the pupils who need it in particular phases of reading, such as word analysis, word differentiation, speed, phrasing, organizing of the thought, and the like tends toward a proper individual development. Some of the provisions of this type could possibly have been classified under the caption of "personal attention." Word and phonic drills for individuals rank relatively high in the whole list of provisions.

A better idea of the frequency with which provisions in each of the seven groups were mentioned by each class of teachers may be had from the summary in Table II.

TABLE II. PERCENT OF TEACHERS WHO STATE THAT THEY

MAKE SOME PROVISION CLASSIFIED UNDER THE GROUP

HEADINGS INDICATED. ORIGINAL' STUDY

\begin{tabular}{|c|c|c|c|c|c|}
\hline Provision for: & Primary & $\begin{array}{l}\text { Inter- } \\
\text { mediate }\end{array}$ & Grammar & $\begin{array}{l}\text { Super- } \\
\text { visors }\end{array}$ & All \\
\hline (A) Testing $\ldots \ldots \ldots \ldots \ldots$ & 10 & 32 & 29 & 46 & 25 \\
\hline (B) Grouping $\ldots \ldots \ldots \ldots \ldots$ & 60 & 44 & 21 & 62 & 49 \\
\hline (C) Gradation of material.... & 44 & 54 & 36 & 54 & 47 \\
\hline (D) Practice...$\ldots \ldots \ldots \ldots$ & 46 & 54 & 43 & 54 & 49 \\
\hline (E) Special help............. & 60 & 61 & 57 & 62 & 59 \\
\hline (F) Interest $\ldots \ldots \ldots \ldots \ldots$ & 15 & 27 & 36 & 31 & 24 \\
\hline (G) Method.............. & 90 & 98 & 93 & 92 & 93 \\
\hline
\end{tabular}

The greatest possible, and in most cases the most desirable, figure would be 100 percent. More than 90 percent suggested some provision which can be classed under method but only half, roughly speaking, suggest any form of provision that may be 
classed under the headings of grouping, gradation of material, practice, or special help. The last is next to method in frequency. Only one-fourth list anything under the heading of testing or interest. The figures of the table, we fully believe, may be taken as indicative of what these teachers actually do. No large percent of them appear to have anything like an adequate comprehension of the problem. If these figures represent the actual facts for teachers of more or less acknowledged success, what must be true of average teachers!

The small percent of those who suggest testing is probably due in part to the fact that testing is rather new. This is especially evident in the case of the primary teachers. We are very much surprised, however, that fewer than a third of the intermediate and upper grade teachers thought of testing as a step toward adequate provision for individual differences. It is positively known that some in whose rooms reading tests had been given within the year did not mention testing. Exposure does not necessarily affect practice. The problem of research workers is much more than inducing people to administer tests. They must be taught how to apply the findings.

Grouping is much more popular with primary teachers and supervisors than with other classes of teachers. Gradation of materials drops off in the grammar grades where it should be strong.

The element of interest in primary grades should be a cause for concern. Only 15 percent apparently make serious efforts to fathom the interests of the individual child. It is entirely possible that this reflects the unusual deference paid to mechanical methods which appear to be blotting out all conceptions of the importance of interest. In the grammar grades, where teachers are forced by circumstances to study interests, the percent opposite interest is more than twice what it is in the primary grades.

By way of comparison it will be interesting to note what happened when these teachers were furnished with a list of all of the significant provisions already found and were asked to check the ones they were using. Table III gives facts similar to those of Table II, but for the suggested list. It is evident from this that teachers either failed on the original inquiry to record all that they were doing, or that they were ready to acquiesce very largely 
TABLE III. PERCENT OF TEACHERS WHO STATE THAT THEY MAKE SOME PROVISIONS UNDER THE GROUP HEADINGS

INDICATED. SUGGESTED LIST

\begin{tabular}{|c|c|c|c|c|c|}
\hline Provisions for: & Primary & $\begin{array}{l}\text { Inter- } \\
\text { mediate }\end{array}$ & Grammar & $\begin{array}{l}\text { Super- } \\
\text { visors }\end{array}$ & All \\
\hline (A) Testing........ & 35 & 81 & 100 & 91 & 74 \\
\hline 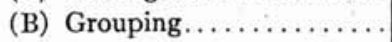 & 94 & 76 & 100 & 100 & 89 \\
\hline (C) Gradation of material.... & 94 & 100 & 100 & 100 & 98 \\
\hline (D) Practice...$\ldots \ldots \ldots \ldots$ & 100 & 100 & 100 & 100 & 100 \\
\hline (E) Special help ............ & 100 & 95 & 82 & 100 & 95 \\
\hline (F) Interest. . . . . . . . & 100 & 86 & .100 & 100 & 93 \\
\hline 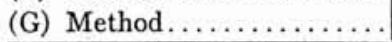 & 100 & 100 & 100 & 100 & 100 \\
\hline
\end{tabular}

in the privisions suggested to them. It is our candid opinion that Table II represents more nearly what is actual practice. It indicates what these teachers have thought about sufficiently to put into practice. Table III represents more nearly an ideal.

A further check on the breadth of teachers' conceptions of the problem may be had by noting the number of groups of provisions to which they contributed. Table IV indicates for both the original study and the suggested list the percents of each class of teachers who suggested provisions: (a) under four or more of the seven groups used in preceding tables; and (b) under three or fewer of them.

TABLE IV. PERCENT OF TEACHERS WHO CONTRIBUTED TO VARIOUS NUMBERS OF THE SEVEN GROUPS LISTED

IN PRECEDING TABLES

\begin{tabular}{|c|c|c|c|c|}
\hline \multirow{3}{*}{ TYPE OF TEAChER } & \multicolumn{4}{|c|}{ Number of Groups of Provisions } \\
\hline & \multicolumn{2}{|c|}{ Original Study } & \multicolumn{2}{|c|}{ Suggested List } \\
\hline & 3 or less & 4 to 7 & 3 or less & 4 to 7 \\
\hline Primary..$\ldots \ldots \ldots \ldots \ldots$ & 54 & 46 & 0 & 100 \\
\hline Intermediate............ & 42 & 59 & 5 & 95 \\
\hline Grammar.............. & 64 & 36 & 0 & 100 \\
\hline Supervisors............ & 23 & 77 & 2 & 98 \\
\hline All $\ldots \ldots \ldots \ldots \ldots \ldots \ldots$ & 48 & 52 & 2 & 98 \\
\hline
\end{tabular}

In the original study nearly half failed to qualify for entry in more than three groups. The grammar-grade teachers appear to have the most limited viewpoint, for nearly two-thirds of them 
failed to offer anything which could be included in four or more groups. The supervisors and superintendents give evidence of their broader conception of the problem. The summary for the suggested list is only what we should expect after seeing Table III.

When the teachers checked the suggested list, they gave us a cue to the measures which, in general, are most frequently favored. Table $\mathrm{V}$ indicates, in the order of frequency, the percent of teachers who checked each of the 28 provisions. Those most often checked by teachers of different types are indicated by a plus sign and those most seldom by a minus sign. There were but 61 returns, however, and for that reason the results must be discounted. Moreover, the wording of certain of the provisions may have caused some misinterpretations. The fact that we were dealing with provisions for individuals and not with class provisions may not always have been kept clearly in mind.

As any keen student will detect, the order falls short of being one of merit. We can judge from it which of the measures are relatively popular with each class of teachers and which ones are either not favored or are not sufficiently familiar to them. The five provisions most favored by all teachers are silent reading, use of thought questions, voluntary reading in free periods, home reading, and special help for specific defects. Strangely enough, voluntary reading appeared to occupy a much lower position among upper-grade teachers. It is possible that this is due in a measure to the formal programs of these grades, which permit little freedom or initiative. Among primary teachers voluntary reading receives first place. Silent reading, special help, and grouping by ability come next. Intermediate-grade teachers place silent reading and use of thought questions first. Voluntary reading is third. Upper-grade teachers place educational testing and home reading first. Silent reading, use of thought questions, thought drills, and having the best read for inspiration to the poorer are other provisions that rank high with these teachers. Every supervisor and superintendent checked silent reading, thought questions, special help, and grouping by ability. As might have been surmised, they checked a larger number of items than any other group.

The items checked by fewer than one-half of the 61 teachers will be seen from the table. It is to be regretted that so few 
TABLE V. RANK OF THE VARIOUS PROVISIONS FOR INDIVIDUAL DIFFERENCES-BY PERCENT OF FREQUENCY. SUGGESTED LIST

\begin{tabular}{|c|c|c|c|c|c|}
\hline Provisions & All & $\begin{array}{l}\text { Pri- } \\
\text { mary }\end{array}$ & $\begin{array}{l}\text { Inter- } \\
\text { mediate }\end{array}$ & $\begin{array}{l}\text { Gritm- } \\
\text { mar }\end{array}$ & $\begin{array}{l}\text { Super- } \\
\text { visors }\end{array}$ \\
\hline${ }^{*}$ Silent reading $(G) \ldots \ldots \ldots \ldots$ & 97 & $94(+)$ & $100(+)$ & $91(+)$ & $100(+)$ \\
\hline Use of thought questions $(G) \ldots \ldots \ldots$ & 93 & 82 & $100(+)$ & $91(+)$ & $100(+)$ \\
\hline${ }^{*}$ Voluntary reading in free periods (D).. & 87 & $100(+)$ & $95(+)$ & 45 & 91 \\
\hline${ }^{*}$ Home reading (D) $\ldots \ldots \ldots \ldots \ldots \ldots$ & 87 & 71 & $90(+)$ & $100(+)$ & 91 \\
\hline${ }^{*}$ Special help for specific defects (E).... & 87 & $94(+)$ & 81 & 73 & $100(+)$ \\
\hline $\begin{array}{l}\text { Oral reading or dramatizing assigned } \\
\text { according to individual ability (C) .. }\end{array}$ & 85 & 77 & $90(+)$ & 82 & 91 \\
\hline Best read for inspiration to poorer $(\mathrm{F})$. & 84 & 88 & 76 & $91(+)$ & 91 \\
\hline${ }^{*}$ Pupils in small groups by ability (B)... & 82 & $94(+)$ & 62 & 82 & $100(+)$ \\
\hline $\begin{array}{l}\text { Poorer called on more frequently in oral } \\
\text { recitation (D) } \ldots \ldots \ldots \ldots \ldots \ldots \ldots \ldots\end{array}$ & 79 & 71 & 81 & 73 & 91 \\
\hline Rapid cover in silent reading (D).... & 74 & 77 & 71 & 73 & 82 \\
\hline${ }^{*}$ Material graded to individual ability $(\mathrm{C})$ & 74 & 77 & 62 & 82 & 82 \\
\hline${ }^{*}$ Thought drills $(G) \ldots \ldots \ldots \ldots \ldots \ldots$ & 72 & 59 & 71 & $91(+)$ & \$2 \\
\hline *Tests of rate and comprehension (A)... & 70 & $29(-)$ & 76 & $100(+)$ & 91 \\
\hline $\begin{array}{l}\text { Materials chosen according to individual } \\
\text { interests }(\mathrm{F}) \ldots \ldots \ldots \ldots \ldots \ldots \ldots \ldots \ldots\end{array}$ & 69 & 65 & 67 & 73 & 82 \\
\hline Material of pupils' own choosing(C)... & 69 & 65 & 71 & 45 & 91 \\
\hline Phrase drills $(\mathrm{G}) \ldots \ldots \ldots \ldots \ldots \ldots \ldots$ & 69 & 82 & 71 & $36(-)$ & 73 \\
\hline Word ar & 69 & 88 & 62 & $27(-)$ & 91 \\
\hline Illustrate material read by drawing (G) & 66 & 77 & 57 & 45 & 82 \\
\hline Use of better pupils to help poorer (E). & 62 & 59 & 71 & 45 & 73 \\
\hline Speed drills $(\mathrm{G}) \ldots \ldots \ldots \ldots \ldots \ldots \ldots \ldots$ & 61 & 65 & 67 & 45 & $64(-)$ \\
\hline Moti & 61 & 65 & 57 & 45 & 82 \\
\hline Individual choice of parts $(\mathrm{F}) \ldots \ldots \ldots$ & 61 & 59 & 52 & 73 & 73 \\
\hline${ }^{*}$ Problem assignment $(G) \ldots \ldots \ldots \ldots$ & 48 & $29(-)$ & $48(-)$ & 64 & $64(-)$ \\
\hline Home help (E) .................. & 48 & 47 & $43(-)$ & $27(-)$ & 82 \\
\hline *Intelligence tests (A) . . . . . . . . & 48 & $18(-)$ & 52 & 73 & $55(-)$ \\
\hline $\begin{array}{l}\text { Pupils arranged in small groups } n o t \text { by } \\
\text { ability (B) } \ldots \ldots \ldots \ldots \ldots \ldots \ldots \ldots \ldots\end{array}$ & 46 & $29(-)$ & $43(-)$ & $36(-)$ & 91 \\
\hline Additional periods (D) $\ldots \ldots \ldots \ldots \ldots$ & 34 & 47 & $14(-)$ & $9(-)$ & 73 \\
\hline Dramatization for certain pupils $(G) \ldots$ & 33 & $29(-)$ & $29(-)$ & 45 & $36(-)$ \\
\hline
\end{tabular}

Note: The provisions starred represent those which we believe to be among those most worthy of consideration. Capital letters following each provision indicate the group under which it was classified-(A) testing; (B) grouping of pupils; (C) graduation of materials; (D) amount of reading practice; (E) attention given to individuals; (F) development of individual interests; (G) instruction. Figures followed by plus signs indicate provisions most frequently favored by each class of teachers. Similarly, mimus signs indicate those least favored.

The figures above are to be taken merely as suggestive. They are based upon only 61 returns as follows: primary 17 ; intermediate 21 ; grammar 11 ; supervisor 11 ; mixed 1. 
teachers are familiar enough with the problem method to put it into reading practice. This method could be used more successfully than most of those contained in our list as a means of providing for individual differences. The application of intelligence tesls as we might expect occupies a low place because teachers have not been trained to use them.

The provisions which the writer deems among those possessing on the whole the most merit have been starred in the table. Several others are good. Few should be discarded entirely. These conclusions are based not only upon the study but upon observations of the classroom efforts of a number of teachers who were consciously attempting to meet the problem.

Our main purpose in this study, however, has not been to evaluate the provisions in use but to find, if possible, those that are being employed by successful teachers together with the suggustions to be gained for the less-experienced teacher. We believe the measures for meeting individual differences listed in Tables I and $\mathrm{V}$ represent a variety that will be suggestive. It is not a complete list. The validity of several of the proposed measures needs to be tested experimentally. Our best hope is that the study may serve as a stimulus to further investigation in this field. We trust that it will cause a few teachers at least to form a broader conception of the problem of meeting individual differences in reading ability. 